\title{
As primeiras epidemias de cólera em Moçambique
}

(Editado na Revista de Saúde Pública, 28(5): 332-6, 1994)

Ilmo Editor,

Em sucessivas investigações realizadas pelo Gabinete de Epidemiologia referente à cólera em Moçambique, pudemos constatar que a epidemia de cólera de 1973 era a terceira ocorrida em Moçambique e não a primeira como afirmamos em recente publicação na Vossa Revista'.

Segundo fontes portuguesas ${ }^{2.3}$, no Relatório do $\mathrm{Dr}$. António Justino de Faria Leal, cirurgiāo da $2^{\mathbf{a}}$ classe da Armada Real Portuguesa, publicado nos Boletins Oficiais $n^{\circ} 24,25$ e 26 do ano de 1859, se descreve a primeira epidemia de cólera, em Moçambique, ocorrida em 19594, como extensăo da terceira pandemia, iniciada em 1852. Na sua evoluçăo, a epidemia atravessou o Golfo Pérsico, atingindo Arábia, onde afectou um grande número de peregrinos da Meca, depois atingiu a costa oriental da África, nomeadamente Melinde, Zanzibar e Quiloa, e de alí Moçambique ${ }^{s}$. As regiões afectadas foram a Ilha de Moçambique, a Ilha de Ibo e a zona do continente vizinho a Ilha de Moçambique, registrando-se um total de 2.541 bbitos $^{3}$.

A segunda epidemia reportada em Moçambique no Século XIX ocorreu durante a $4^{\prime \prime}$ pandemia afectando Cabo Delgado, Ilha de Moçambique, Angoche e Sena. A epidemia parece ter começado a inícios de 1870 no Norte do País, e durou até o mês de Março de 1871, caracterizando-se por "uma maior expansão, maior benignidade e tendência para se tornar endémica"’.

Dr. Miguel Aragon; $M D$.

Dr. Avertino Barreto; $M D$. $M S c$.

Dra. Maria Tallarico; MD. MSc.

\section{Referências Blbliográtlcas}

1. ARAGON, M. et. al. Epidemiologia da cólera em Moçambique período 1973-1992. Rev. Saúde Pública, 28: 332-6, 1994.

2. FOLGOSA, J.M. A arte de curar em Moçambique. Lourenço Marques (Cidade de Maputo), 1959. p: 133-8.

3. REIS, C. S. Duas epidemias de cólera em Moçambique. J. Soc. Ciênc. Mĕd. Lisboa, 137 (3): 275-300, 1973.

4. FARIAS LEAL, A.J. Relatório. Boletim Oficial. Arcbivo bistórico de Maputo-Moçambique, $\mathrm{n}^{2} 25$ de 18 de juntho de 1859 .

5. POLLITZER, R. Cholera. Geneva, World Health Organization, 1959 (WHO Monograph Series 43). 